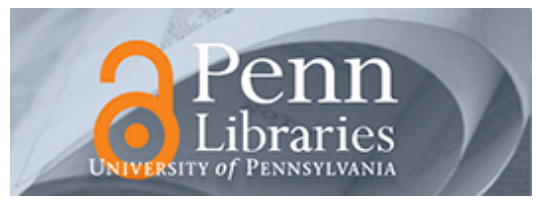

University of Pennsylvania

ScholarlyCommons

Management Papers

Wharton Faculty Research

$11-2014$

\title{
Do Parents Matter? Effects of Lender Affiliation Through the Mortgage Boom and Bust
}

Claudine M. Gartenberg

University of Pennsylvania

Follow this and additional works at: https://repository.upenn.edu/mgmt_papers

Part of the Business Administration, Management, and Operations Commons, Business and Corporate Communications Commons, Business Intelligence Commons, Corporate Finance Commons, Finance and Financial Management Commons, Management Information Systems Commons, Management Sciences and Quantitative Methods Commons, Organizational Behavior and Theory Commons, and the Strategic Management Policy Commons

\section{Recommended Citation}

Gartenberg, C. M. (2014). Do Parents Matter? Effects of Lender Affiliation Through the Mortgage Boom and Bust. Management Science, 60 (11), 2776-2793. http://dx.doi.org/10.1287/mnsc.2014.1944

At the time of this publication Dr. Gartenberg was affiliated with NYU, but she is now a faculty member at the University of Pennsylvania.

This paper is posted at ScholarlyCommons. https://repository.upenn.edu/mgmt_papers/330

For more information, please contact repository@pobox.upenn.edu. 


\title{
Do Parents Matter? Effects of Lender Affiliation Through the Mortgage Boom and Bust
}

\begin{abstract}
It is widely acknowledged that the 2007 mortgage crisis was preceded by a broad deterioration in underwriting diligence. This paper shows that this deterioration varied by the industry affiliation of mortgage lenders. Loans issued by homebuilders and stand-alone lenders were significantly less likely to default than loans issued by depository banks and affiliates of major financial institutions. I argue that homebuilders and stand-alone lenders had the least financial capacity to hold mortgages, and their resulting need to sell loans quickly on the secondary market forced them to issue safer loans. Tests of other explanations, including differences in information and incentives to avoid foreclosure externalities, receive little support. This study highlights a novel means by which firm boundaries influence firm adaptation to changing market conditions by defining the boundaries of the internal capital markets and hence the relative constraints of constituent units.
\end{abstract}

\section{Keywords}

corporate finance, financial institutions, banks, organization studies, strategy, industrial organization, firm objectives, organization and behavior, real estate

\section{Disciplines}

Business Administration, Management, and Operations | Business and Corporate Communications | Business Intelligence | Corporate Finance | Finance and Financial Management | Management Information Systems | Management Sciences and Quantitative Methods | Organizational Behavior and Theory | Strategic Management Policy

\section{Comments}

At the time of this publication Dr. Gartenberg was affiliated with NYU, but she is now a faculty member at the University of Pennsylvania. 


\title{
Do Parents Matter? Effects of Lender Affiliation through the Mortgage Boom and Bust
}

\author{
Claudine Gartenberg \\ NYU Stern School of Business, 40 West $4^{\text {th }}$ Street, New York, NY 10012, \\ cgartenb@stern.nyu.edu
}

It is widely acknowledged that the 2007 mortgage crisis was preceded by a broad deterioration in underwriting diligence. This paper shows that this deterioration varied by the industry affiliation of mortgage lenders. Loans issued by homebuilders and standalone lenders were significantly less likely to default than loans issued by depository banks and affiliates of major financial institutions. I argue that homebuilders and standalone lenders had the least financial capacity to hold mortgages, and their resulting need to sell loans quickly on the secondary market forced them to issue safer loans. Tests of other explanations, including differences in information and incentives to avoid foreclosure externalities, receive little support. This study highlights a novel means by which firm boundaries influence firm adaptation to changing market conditions, by defining the boundaries of the internal capital markets and hence the relative constraints of constituent units.

Key words: Corporate finance; Financial institutions; banks; Organization studies; Strategy; Industrial organization; Firm objectives, Organization and behavior; Real estate

History: First submitted January 10, 2012, final version: February 20, 2014. 


\section{Introduction}

One of the precursors to the housing crisis that began in 2007 was a sharp decrease in mortgage underwriting quality earlier in the 2000s (Demyanyk and Van Hemert 2011; Dell'Ariccia et al. 2009). Despite substantial research on the underlying factors that led to this lending deterioration (e.g., Mian and Sufi 2009; Rajan et al. 2012; Keys et al. 2010), the role of mortgage lenders has received relatively little attention. Aside from exploring the effects of vertical disintegration and the corresponding decline of "skin in the game” (Demiroglu and James 2012; Purnanandam 2011), studies generally assume lenders to be relatively homogeneous. This, however, is far from the case. All major depository banks had lending units during the period in question, as did major investment banks, many insurance companies and national homebuilders. The heterogeneity of parent industries raises the question: How did these units' corporate affiliations affect lending quality during this period? The answer to this question is relevant not only for isolating underlying causes for the housing downturn, but also for addressing a long-standing question in corporate strategy: How do firm boundaries influence how firms adapt to changing external conditions?

This latter question has led to a large and active research agenda. Recent studies have typically adopted a transactions cost (Williamson 1975, 1985) or capability development (Wernerfelt 1984; Barney 1986) approach to the question. A small sample of these studies reveals that firm boundaries influence complex problem solving (Macher 2006), coordination in uncertain and changing environments (Forbes and Lederman 2009) and capability development in general (Jacobides and Winter 2006). Other studies emphasize the darker side of integration as leading to coordination costs (Rawley 2010; Rawley and Simcoe 2010; Zhou 2011) and agency or social conflicts (Pierce 2012; Nickerson and Zenger 2008). This study, in contrast, suggests a less-explored means by which firm boundaries affect adaptation—through their impact on the relative financial resources and constraints of constituent units.

In the popular view, there is a widespread presumption that lending quality did, in fact, vary by type of parent affiliation. Homebuilders, which sold nearly $30 \%$ of new homes in the U.S during the 2000s and financed up to 70-80\% of these homes, have been subject to several consumer and shareholder lawsuits, as well as government investigations accusing them of engaging in particularly poor lending practices to sell more homes. ${ }^{1,2}$ Furthermore, during this period of unprecedented home sales and price

\footnotetext{
${ }^{1}$ Homebuilders comprised an even larger market share in boom geographies, financing $51 \%$ of all new homes in Phoenix and $47 \%$ in Las Vegas. While mortgages for new homes comprise less than $10 \%$ of the total residential mortgage market in the US, the residential construction industry accounts for approximately 4-5\% of U.S. GDP (source: bipartisanpolicy.org, "Bonfire of the Homebuilders," Businessweek, August 13, 2007 and author's estimates from 10-K filings and mortgage database)

${ }^{2}$ Some cases include: In Re: Beazer Homes USA, Inc . Securities Litigation, Master File No: 1:07-cv-725-CC; Mark Zachary v. Countrywide Home Loans Inc. and Countrywide KB Home Loans; Sodalin Kaing v. Pulte Homes, C09-05057; See, also, HUD Audit Reports 2009-LA-1018, 2006-LA-1014, 2006-LA-1001, as well as SEC and Department of Justice investigations into Beazer Homes.
} 
appreciation, homebuilders' share of new home mortgages grew relative to other lenders' (see Figure 1a). This increased share suggests that homebuilders were "buying deep" into the risk pool to sustain sales growth, particularly as sales began to level off in late 2005 and 2006 (see Figure 1b). In fact, in the aftermath of the collapse, homebuilder mortgages defaulted at roughly $130-150 \%$ of the national average. ${ }^{3}$ This poor performance appears to confirm popular accounts and support prior models of captive finance that explain lower lending quality by in-house lenders as efficient cross-subsidization of the durable good (Barron et. al. 2008).

\section{$<<$ INSERT FIGURE 1 ABOUT HERE $>>$}

This study disputes this interpretation. It finds that the higher default rate of homebuilder loans is entirely attributable to the concentration of new construction in particularly risky geographies and, in fact, controlling for geographic factors, homebuilders applied significantly more diligence than other lenders. Using a dataset of 212,058 mortgages issued by all market participants in the 100 zip codes that experienced the most new home construction from January 1999 to mid-2009, I evaluate lending quality as the hazard of loan default after controlling for macroeconomic, borrower-risk and contract characteristics. I compare the default hazard across four classes of lenders: homebuilders, standalone lenders, depository banks and lenders affiliated with large financial institutions. Rather than underperforming the market, homebuilder loans perform significantly better than similar loans issued by depository banks and affiliates of large financial institutions. Interestingly, these quality differences emerge only with the peaks of the housing boom in 2005 and 2006. The relative hazard of mortgage default for loans issued by depository banks increased from being statistically indistinguishable from that of homebuilders’ loans between 1999 to 2004 to being 36\% higher in 2005 and 2006.

I explore three potential explanations for this finding. First, I ask whether financial constraints explain lending quality differences. In this scenario, firms with more constrained capacity to hold loans, including homebuilders and most standalone mortgage banks, underwrote mortgages that could be sold quickly and with a lower chance of forced repurchases due to poor underwriting quality. ${ }^{4}$ The second explanation focuses on information differences between lenders. Here, homebuilders produce more soft information about customers and local market conditions as a byproduct of their home sales and land operations. They use this information to screen customers more thoroughly and to respond better to imminent downturns in their local markets. The third explanation asks whether homebuilders' internalization of the costs of foreclosures in their subdivisions - costs that other lenders do not beardrives higher lending standards.

\footnotetext{
${ }^{3}$ Source: CoreLogic

${ }^{4}$ Forced repurchases arise from early default, violation of stated underwriting guidelines or fraud—all of which increase with poor underwriting.
} 
Overall, I find support for the first explanation and no strong evidence for the second or third. Specifically, the hazard of loan default, conditional on a loan's observable characteristics, is positively related to the average loan holding period for a firm and to a supplementary pricing-related proxy for mortgage holding capacity. This proxy is defined as the degree to which the hard information on a loan explains loan prices. The logic behind this measure follows Rajan et al. (2013), who show that as securitization levels increased, loan pricing was increasingly explained by hard information. Taken together, I interpret these results as evidence that markets did, in fact, exert a disciplining force at the height of the boom, particularly for lenders with limited loan-holding capacity. ${ }^{5}$

These findings suggest an interesting and previously unexplored relationship between internal capital markets and firm adaptation. One defining feature of internal capital markets is that managers engage in "winner-picking," allocating capital to units at levels above what would be available via the external market (Williamson 1975; Donaldson 1984). Stein (1997) also demonstrates that, in order to provide capital to winners, managers must engage in so-called "loser-sticking”: undersupplying capital to other units, even if those units have profitable investment opportunities. A given unit, therefore, may be resource-constrained within one firm and resource-rich in another, solely as a function of the other opportunities within the firm boundaries. These constraints, in turn, influence how the firm adapts to changing conditions.

In the housing context, the findings are consistent with homebuilders' mortgage units being “loser-stuck,” particularly as the housing boom progressed and headquarters allocated an increasing share of capital to housing operations. The findings further suggest that these "loser-stuck" units and other constrained lenders responded to market growth with relatively more discipline than unconstrained lenders.

For integrated homebuilders, this result is counterintuitive, as prior research on captive lending and lender segmentation predicts that the mortgage units might optimally lower their screening levels in order to subsidize housing units (Barron et al 2008) or as they specialize (Carey et al 1998; Remonola and Wulfekuhler 1992). The results of this paper show the opposite, that homebuilders both served observably

\footnotetext{
${ }^{5}$ These findings are consistent with statements from industry participants interviewed for this study. For example, a former head of the mortgage affiliate of one of the largest national homebuilders stated during an interview: "There is a stereotype that securitization led to this hot potato, that's where the risk was. In reality . . . the opposite was true. It was the portfolio lenders, including the securitization issuers, who went out like riverboat gamblers. If I am a bank, I can put \$8 billion into a new product tomorrow. If I rely on the market [to fund mortgages], there's only so quickly it can adapt to new products. The market was a well-oiled machine and relied on known products. Anything new was done in-house. . . . [W] never originated a mortgage without knowing where we would place it.” The former head of the lending affiliate of another large national homebuilder made a similar remark when asked what drove strict underwriting standards: "We made $15-40 \%$ margin on our homes; why tie up capital in mortgages? We had a $\$ 100$ million line, [and] we had to turn it over every 30 days to free up capital to make new loans.”
} 
less risky segments and had higher underwriting diligence. This result also runs counter to prior research that has shown that integrated firms are generally less disciplined than markets (Williamson 1985).

This research is closely related to two recent papers. Seru (2013) shows that conglomerates reduce $R \& D$ productivity in acquired firms, particularly in acquirers with active capital markets. ${ }^{6}$ Lyandres (2006) suggests that conglomerates affect rival competition in product markets by requiring divisions to share a unified firm-wide capital structure. While the specific mechanisms differ, both these papers and the current study note that end-market activity is influenced by internal capital allocation that is in turn determined by firm boundary choice.

This paper also makes two contributions to the large and growing literature on the causes and consequences of the recent housing crisis (e.g., Shiller 2008; Mayer, Pence and Sherlund 2009; Foote et al. 2008). First, it provides evidence that contradicts the perspective that the "originate to distribute" lending model, on its own, led to poor underwriting practices during this period (Purnanandam 2011, Demiroglu and James 2012). A high-securitization environment may, indeed, have contributed to poor systemic underwriting (Keys et al. 2010; Rajan et al. 2013) and exacerbated the foreclosure crisis (Piskorski et al. 2010). Within this environment, however, I find that firms with limited capacity to hold loans before selling them to third parties were more disciplined than firms with more funding options. Second, this paper shows that the systemic deterioration in lending quality over the course of the boom (Dell'Ariccia et al. 2009) was not evenly shared by originators. In fact, some of the firms that displayed the greatest deterioration-depository banks—-were also the most regulated, a finding similar to that of Keys et al. (2009).

Lastly, this paper contributes to research on credit markets. Prior credit research outside of a housing context has shown that specialized lenders, which include captive industrial lenders analogous to the homebuilders in this paper, serve observably riskier customer segments, independent of geography, (Carey et al. 1998; Barron et al. 2008) and show evidence of agency issues (Pierce 2012). None of these findings were validated in this context; in fact, they were contradicted.

\section{Mortgage industry in the 2000s}

The first half of the 2000s was marked by $100 \%$ home price appreciation between 2000 and $2006,{ }^{7}$ increased construction activity from 1.5 million new homes in mid-2000 to 2.3 million in early 2006, and increased mortgage originations from \$1 trillion in 2000 to $\$ 2.7$ trillion in $2006 .{ }^{8}$ Concurrent

\footnotetext{
${ }^{6}$ In the management literature, Baysinger and Hoskisson (1989) and Hoskisson et al. (1993) note a similar empirical finding, although they attribute the costs to inefficient monitoring and incentives associated with diversification, rather than internal capital markets.

7 Based on both the Case-Shiller Composite 20 index and the LoanPerformance House Price Index, source: www.calculatedriskblog.com, accessed June 23, 2010.

${ }^{8}$ Source: Census Bureau.
} 
with these trends was an increase in securitization, combined with an increasing reliance on pricing loans based on "hard information,” particularly a consumer’s FICO (credit) score (Rajan et al. 2013). ${ }^{9}$

Beginning in 2005 and 2006, national home prices and sales both leveled off. In the first half of 2007, the private-label (non-government-backed) securities market effectively shut down, leading to the failure of numerous mortgage lenders. By January 2010, national home prices had fallen 30\% from their peak, including 55\%, 50\%, and 46\% in Las Vegas, Phoenix, and Miami, respectively. By March 2010, $24 \%$ of all U.S. residential properties with mortgages were worth less than the mortgages on the properties, including $70 \%$ of all properties in Nevada, $51 \%$ in Arizona and $48 \%$ in Florida. ${ }^{10}$ This housing crash triggered a financial crisis that precipitated the largest recession since the Great Depression.

\subsection{Mortgage origination}

The mortgage industry spans both the primary market to supply loans to consumers and the secondary securitization market, in which originators transfer the loans via bulk sales to third parties (or to a different division within the same firm) and pool them into trusts that issue mortgage-backed securities. For bulk sales, lenders periodically assemble a pool of loans and either offer the pool to a specific purchaser or place it for bid. Purchasers have two levers to ensure loan quality. First, they can "kick out" loans from the pool that they deem to be poor quality. ${ }^{11}$ Lenders can then attempt to re-offer kicked out loans to other buyers; however, these loans often take longer to place and are sold at a discount. Second, they can "put back" loans by forcing lenders to repurchase the loans post-sale if any representations and warranties in the loan purchase agreements are violated. Like kicked-out loans, these repurchased loans typically can be resold, but only after a period of time and often at a loss rate of approximately 25\%, according to practitioners interviewed for this study. While no industry-wide data are available, practitioners report that purchaser due diligence began increasing in early 2005 as home price appreciation began to moderate and then dramatically increased in 2006 and 2007 as home prices leveled and defaults rose. ${ }^{12}$

I categorize mortgage lenders into four parent industries used in later analyses: standalone mortgage lenders (such as Countrywide); depository banks (including both commercial banks such as Bank of America and thrifts such as Washington Mutual); mortgage lenders affiliated with larger firms

\footnotetext{
${ }^{9}$ FICO stands for "Fair Isaac Corporation,” the firm that created and manages the consumer credit scoring model.

${ }^{10}$ Sources for this paragraph include New Century Financial Corporation Examiner's Report, Case No. 07-10416. The Mortgage Lender Implode-o-Meter lists 384 lender failures since late 2006, http://ml-implode.com/, accessed June 14, 2010, Source: S\&P/Case-Shiller via www.calculatedriskblog.com accessed May 21, 2010, CoreLogic negative equity report.

${ }^{11}$ For example, New Century Financial Corporation experienced a 14.95\% kick-out rate by December 2006 prior to bankruptcy in early 2007, pg 161.

12 The bankruptcy examiner for New Century Financial Corporation reported that, in 2005, 20-30\% of the loan files in New Century pools would be fully examined by investors. By 2006, 30-35\% of loan files had been examined, and by late 2006, some investors had examined every loan file. Page 163.
} 
(including the lending arms of AIG, GE Capital and Lehman Brothers); and homebuilders with financing affiliates.

\subsection{Homebuilders in-house mortgage units}

Homebuilders established mortgage units beginning in the 1960s and continuing through the 1990s. By 1999, nearly all the national and large regional homebuilders had established internal divisions with specialized loan officers and underwriters, while mid-sized homebuilders typically had joint ventures with financial institutions. These in-house units generally funded only mortgages associated with homes constructed by the parent homebuilder. In interviews, homebuilder executives report that the rationale for establishing in-house units was the desire to reduce customer dropouts during the home closing process by improved coordination between financing and home sales activities.

During this period, homebuilders and most standalone mortgage lenders disposed of their loans on the secondary market through sales to large financial institutions. Prior to these sales, mortgages were funded by revolving credit lines with financial institutions. These credit lines were typically small relative to home sales. For example, Pulte Homes—-the largest U.S. homebuilder—reported a \$955 million credit line in 2006. With annual home sales of $\$ 14$ billion, this credit line allowed for mortgages to be held for 16 to 30 days prior to sale. ${ }^{13}$ A kickout rate of $14.95 \%$, the level reached by New Century Financial Corporation in December 2006, would consume 25-40\% of the line. ${ }^{14}$

\section{Underwriting differences by lender affiliation}

\subsection{Data and sample selection}

The primary data sources are county deed records and the Loan Performance Servicer database, which were merged for this study in cooperation with CoreLogic, the data provider. The county deeds database consists of the complete public deed filings, including all liens related to purchase, refinancing mortgages and notices of default and foreclosure. The Loan Performance Servicer database consists of mortgage servicer-provided information that covers approximately $80 \%$ of all mortgages in the United States and includes borrower risk information and important contract provisions. ${ }^{15}$ I supplement these two sources with data on the lender that was hand-collected or merged from Compustat (for public firms) and macroeconomic data from the Census Bureau, the Bureau of Labor Statistics, Freddie Mac and the Federal Reserve Bank.

\footnotetext{
13 The calculation uses data reported in Pulte 10K for 2006: (\$955 million credit facility *85\% utilization)/( $\$ 14$ billion * 90\% capture rate $* 80 \%$ loan-to-value $)=29$ days. Pulte reported an average of $47 \%$ utilization-common in the industry to allow for seasonal fluctuations - which allowed mortgages to be held for 16 days before sale.

${ }^{14}$ Assuming a 60-90 day placement rate.

${ }^{15}$ The Loan Performance Servicer database should not be confused with the commonly-used Loan Performance Securities database, which covers the subprime market only.
} 


\subsubsection{Variables}

The outcome variable is an indicator of whether a notice of mortgage default was filed with the county, together with the date of filing. ${ }^{16}$ Variables that control for macroeconomic conditions and mortgage features are listed in Appendix A. Lender industry categories and characteristics were hand-collected, merged from Compustat or generated from the mortgage data. Because of the long tail of mortgage lenders in the database, industry categories were assigned to a sufficient number of lenders to cover $80 \%$ of the loans in the database. The 270 hand-coded lenders were assigned to four categories: homebuilders (SIC codes 1520, 1531), depository banks (SIC codes 6020, 6021, 6022, 6035), standalone mortgage lenders (SIC codes 6162, 6163), and affiliated mortgage lenders (SIC codes 4213, 6141, 6159, 6172, 6211, 6311, 6331, 6531, 6798, 7200). The four categories include 34 homebuilders, 75 depository banks, 132 standalone mortgage lenders, 46 large affiliated mortgage lenders, and 3287 small miscellaneous firms. Ten of the 34 homebuilders were joint ventures with banks. Although their homebuilder classification was retained, a joint-venture flag was added to all specifications. Joint-venture-funded loans comprise $15 \%$ of all homebuilder-financed loans in the sample. The remaining firms were allocated either to depository banks if their names included certain search terms or to the "small miscellaneous" category. $^{17,18}$

\subsubsection{Sample selection and descriptive statistics}

The sample was constructed from all county deed filings for the top 100 zip codes for new home construction from 1999 to 2009. The zip codes are located mainly within California, Arizona, Nevada, Texas and Florida, with the highest concentrations of construction in Las Vegas, Nevada and Phoenix, Arizona. While not a nationally representative sample, the sample spans geographies that experienced substantial downturns (e.g., Nevada, Arizona and Florida), as well as those that were more stable (e.g., Texas and North and South Carolina). In aggregate, the combined home-price index tracks the national home price index closely. ${ }^{19}$ Relative to a national sample, this dataset includes a higher proportion of new home construction and, within new homes, a higher proportion of homes sold by national homebuilders.

\footnotetext{
${ }^{16}$ Conditional on the mortgage not prepaying due to resale or refinance, which are treated as non-failure exits.

17 The depository banks also include 401 small banks with a mean (median) of 26 (17) loans that had "Bank," "BK," "FSB," "CU," or "FCU” in their name, contributing less than $4 \%$ of depository bank loans. These banks do not materially affect the empirical results.

18 The smallest ten lenders that were coded each contributed an average of 38 loans, while the largest ten lenders contributed an average of 26,170 loans; therefore, the incremental contribution of each additional lender was minimal.

${ }^{19}$ This sample experienced an 80\% rise and 33\% decline between 1999 and 2009, versus the national sample's 95\% rise and 32\% decline during the same period (source: Case-Shiller US National Home Price Index).
} 
As such, the sample enables greater statistical power to compare loan quality between national homebuilder and financial lenders. ${ }^{20}$

The initial deed filings were screened for new-construction purchase mortgages, which provide an initial sample of 779,315 mortgages originated between January 1999 and September 2009. All mortgages designated as corporate-owned, interfamily transfers or private party sales, and all condominiums, townhouses and other miscellaneous property types were then excluded. Mortgages with substantial missing or duplicate data (184,925 records) and FHA and VA mortgages (117,718 records) were also excluded. ${ }^{21}$ After these exclusions, 476,672 purchase mortgages from the county filings were submitted to CoreLogic to be merged with the Loan Performance Servicer database. The match rate between the two databases was $44 \%$, providing a final sample of 212,058 mortgages. Overall, an analysis of the merged sample reveals that the data are generally unbiased for this study, although the sample is not fully representative of the submitted dataset. Table 1 shows the descriptive statistics on the merged database (refer to Appendix A for variable definitions).

Overall, the descriptive statistics show that homebuilders generally targeted higher credit customers, issued mortgages with more conservative contract structures (higher proportion of fixed rate mortgages, lower proportion of negative amortization, interest-only and prepayment penalty clauses), and had lower aggregate default rates.

\section{$<<$ INSERT TABLE 1 ABOUT HERE $>>$}

\subsection{Empirical approach}

I use a Cox hazard model to evaluate relative default risk between lender types. This model has several advantages. First, it accounts for home resales and mortgage refinancing that lead to non-default-related exits from the dataset. Second, it allows for the inclusion of macroeconomic controls that vary post-loan origination, such as local home prices and unemployment and national interest rates. Third, it makes more-realistic assumptions regarding distribution of residuals than a linear model and accounts for rightcensoring of the data. Lastly, it does not impose an underlying functional form on the underlying mortgage default rate over time. ${ }^{22}$

I report all results as hazard ratios, equivalent to odds ratios in logistic models. Since these hazard ratios are exponentiated, they are non-negative, centered on 1 (rather than 0 ) and have a multiplicative

\footnotetext{
${ }^{20}$ While not nationally representative, there is no reason to believe that lending quality patterns differ in this sample from the national average. Conservatively, however, the result can be interpreted as quality patterns in particularly and profitable active markets.

${ }^{21}$ FHA stands for the Federal Housing Authority and VA stands for the Veterans Administration, both government agencies. These mortgages were excluded for two reasons: first, FHA/VA mortgages are governed by separate regulations and, hence, behave differently from conventional mortgages. Most studies, unless specifically focusing on the FHA, exclude these mortgages. Thus, I also exclude them for comparability purposes.

${ }^{22}$ I replicated the analysis using a logit specification and obtained qualitatively identical results.
} 
interpretation. As such, coefficients less than one represent a decrease in the relative hazard and coefficients greater than one represent an increase. The following model is used in the analysis: ${ }^{23}$

$$
\begin{aligned}
& h\left(t \mid x_{i}\right)=h_{0}(t) \exp \left(\alpha+\beta_{0} \text { ParentAffiliation }_{i}+\beta_{1} \text { Macro }_{i}+\beta_{2} \text { Lender }_{i}\right. \\
& \left.+\beta_{3} \text { Risk }+\beta_{4} \text { Contract }_{i}+\beta_{5} \text { Price }_{i}+\beta_{\text {year }} \text { YearFE }_{i}+\beta_{\text {st }} \text { StateFE }_{i}+\varepsilon_{i}\right)
\end{aligned},
$$

where $h\left(t \mid x_{i}\right)$ is the hazard of default of loan $i$ at time $t$, conditional on the loan not being prepaid due to a sale or refinancing event. $h_{0}(t)$ is the baseline hazard. ParentAffiliation is a vector of five indicator variables for homebuilders, standalone mortgage lenders, depository banks, affiliated mortgage lenders and miscellaneous lenders (throughout the analysis, the homebuilders are the omitted lender type unless otherwise specified). Macro is a vector of macroeconomic controls that includes the home price index constructed from repeat sales using the county deed records. Lender is a vector of lender controls; Risk is a vector of standard hard risk metrics on the borrower; and Contract is a vector of mortgage characteristics. Price includes the initial interest rate of the loan for all mortgages and the margin above an index if the loan is an adjustable-rate mortgage. YearFE and StateFE represent vintage (origination) year and state fixed effects. See Appendix A for a more detailed definition of these variables.

The set of coefficients represented by $\beta_{0}$ are the main parameters of interest. If homebuilders issued relatively worse-performing loans than other lender types, then the $\beta_{0}$ estimates will be less than 1.

\subsection{Results}

Table 2 begins with a direct comparison of the default hazard of homebuilders and financial firms pooled across all years of the sample. Column (1) shows the unconditional relative hazard for the years 1999 to 2009. This specification allows for all choices by lenders to vary, including geography, macroeconomic conditions, and years in which to offer loans, as well as choice of borrower risk and contract characteristics. The results show that, allowing for geography and vintage year to vary, homebuilder loans have a lower default hazard than standalone and affiliated mortgage lenders and statistically the same as depository banks and miscellaneous firms. Columns (2) and (3) add in "hard information” controls, including lender and macroeconomic controls and fixed effects for vintage years and states in Column (2) and observable risk and contract characteristics in Column (3). In Column (2), the hazard ratio coefficients on all the lender types are significantly greater than one. For example, the hazard ratio for loans issued by depository banks is now 2.1385, more than twice as high the baseline of 1 for

\footnotetext{
${ }^{23}$ In unreported results, the findings are replicated using logit specifications.
} 
homebuilder loans, the omitted category. The difference between the results in Columns (1) and (2) indicates that homebuilders offered mortgages in riskier geographies, years and macroeconomic conditions than other lenders; however, controlling for those choices, the default hazard is lower. A comparison of the results in Columns (2) and (3) shows that homebuilders targeted safer borrowers than the four financial lender types and that, conditional on that segmentation choice, the default hazard was lower than for financial lenders.

$<<$ INSERT TABLE 2 ABOUT HERE $>>$

Column (4) includes interest rate as a proxy for "soft information.” The logic here is that any borrower risk that is observed by the lenders, but not captured in metrics such as FICO and combined loan-to-value ratio, will be reflected in the interest rates that the lender charges. ${ }^{24}$ This model reflects the full specification in equation (1). The coefficients on the parent affiliation indicators all attenuate compared to Column (3), but they are still greater than 1 and significant. This indicates higher default hazard than for loans issued by homebuilders, even after controlling for loan characteristics.

Overall, Table 2 shows that homebuilders funded mortgages in riskier areas than other lenders. Within these areas, however, they targeted safer borrowers and offered safer mortgage contracts. In addition, after controlling for these choices, they also appeared to underwrite higher-quality loans. This underwriting could be due either to additional screening on soft information not fully reflected in mortgage prices or to a treatment effect in which homebuilders place borrowers into safer loans.

Table 3 reports relative default hazard across different time periods. I run the full specification as in Column (4) in Table 2, subdivided by time period. For space reasons, only $\beta_{0}$, the coefficient on the parent affiliation indicators, is reported. The table shows the results over four main time periods during the housing cycle: the baseline years (1999-2002), the middle boom (2003-2004), the late boom (20052006) and the post boom (2007-2009).

$<<$ INSERT TABLE 3 ABOUT HERE >>

The coefficients on parent affiliation indicators are insignificant during the 1999-2002 and 20032004 periods, indicating no statistical difference in lending standards by parent affiliation for loans issued during those years. During 2005 and 2006, the peak housing period, the coefficients on depository banks and affiliated lenders increase to 1.3582 and 1.5643, significant at the $1 \%$ level. Homebuilders' hazard

\footnotetext{
${ }^{24}$ Since interest rate is both a proxy for soft information and an outcome of other independent variables in the model, there is some question as to whether it should be included as a control. The results in the paper are qualitatively unchanged either way.
} 
remained lower than other lenders' during the post-boom period, 2007-2009, with the coefficient on standalone lenders of 1.5023 and depository banks of 1.4641. Overall, the results in Tables 2 and 3 provide evidence that lending quality did differ by parent affiliation and that these differences emerged only during the peak period of the housing boom, when lending standards were at their lowest level overall.

\section{Explaining lending differences}

I investigate three explanations for these differences. First, homebuilders have more constrained capacity to hold mortgages from origination until secondary market sale, and this constraint led to increased underwriting diligence. Second, homebuilders possessed greater soft information about homebuyers and local geographic conditions, which enabled better screening. Third, homebuilders internalized the costs associated with foreclosures on proximate homes, which led to more diligent underwriting. I focus on the 2005-2006 period for these analyses since differences between lenders were insignificant between 1999 and 2004, and, from 2007 onward, lending differences are fully explained by firms that failed by the end of 2008, reflecting the highly abnormal industry conditions. ${ }^{25}$

\subsection{Constrained mortgage-holding capacity}

The argument for constrained holding capacity is as follows: Mortgage lenders use capital to fund and hold mortgages until the loans can be sold to third-party financial institutions. In general, institutional buyers have the option to reject ("kick out") loans offered by the lender or to force the lender to repurchase ("put back") loans if those loans were found to violate representations and warranties in the loan purchase agreements. Both actions would cause lenders to hold rejected loans until they could be sold. As a result, lenders with more-limited holding capacity should exert more diligence during the underwriting process to minimize this mortgage-holding risk. Under this scenario, homebuilders, following Stein's (1997) “loser-sticking” argument, ration capital to their in-house mortgage units in order to provide resources to their land and construction operations, particularly during periods of high growth. Thus, we should observe homebuilder behavior consistent with constrained lending, especially during peak periods. ${ }^{26}$

\footnotetext{
${ }^{25}$ I define "failure" as an announcement closure of operations recorded by http://ml-implode.com/ or government-backed injection of capital. Overall, $40 \%$ of the firms coded for this analysis failed by the end of 2008 , accounting for $28 \%$ of the loans issued after 2006. Among standalone mortgage lenders, 51\% of loans issued after 2006 were underwritten by firms that failed by the end of 2008. The coefficient on standalone mortgage lenders is explained entirely by firms that failed by the end of 2008 . Mortgage lenders that survived beyond 2008 have a default hazard indistinguishable from homebuilders.

${ }^{26}$ A question that may arise is whether homebuilders could manage the kickout problem by adjusting wholesale pricing rather than loan quality. Unfortunately, I do not have wholesale pricing to investigate this channel. However, it is unlikely to be a large factor for two reasons: first, lowering loan prices would be unlikely to speed disposition since speed was related to originator reputation for quality, and high prices (rather than low) signaled quality (assuming, over the long run, that high prices reflect
} 
While capital rationing is not directly observable, the reported cash flows of public builders provide some support for this argument. Table 4 shows the median cash flow allocated between land purchase, improvement and construction ("housing”) operations and the mortgage units within the eight public homebuilders for which data were available. The first column shows that housing operations consumed more cash than was generated through the internal operations of the firm, with the median cash flow allocated to housing across all years of the sample comprising $127 \%$ of net income. Over time, the allocation of cash to housing operations increased from $86 \%$ of net income at the economic trough in 2002 to $194 \%$ in 2006. The second column shows cash flow allocated to the mortgage units, with a median level of $3.5 \%$ of net income, far below the levels allocated to housing operations. In contrast to housing cash flow, cash flow to mortgage units generally decreased over the housing cycle. In 2006, mortgage units consumed the cash equivalent of $7 \%$ of net income, down from 33\% in 2002. The final column shows the ratio of cash allocated to mortgage units as a percent of cash allocated to housing operations, which shows the same countercyclical pattern.

These patterns are consistent with housing operations receiving relatively more capital as the boom progressed (the "winners" of the internal capital markets) and mortgage units receiving relatively less (the "losers") and, thus, becoming more constrained. This conclusion must be caveated as follows: since cash flow only measures absolute cash allocation and not allocation relative to investment opportunities, it is an imperfect measure of constraints. Conservatively, then, this table is consistent with, but not proof of, loser-sticking of the homebuilder mortgage units.

\section{$<<$ INSERT TABLE 4 ABOUT HERE $>>$}

Two challenges also exist in testing whether these constraints affected lending quality: causal identification and measurement of mortgage-holding capacity in a standard way across lenders with widely varying reporting requirements. In terms of causal identification, the ideal test would be to observe an exogenous shift in firms' mortgage-holding capacities, followed by a corresponding change in lending quality. However, no such experiment occurred during this time period. Therefore, the relation between holding capacity and lending quality is associative. Any causal interpretation is based on insight from practitioner interviews and ruling out alternative explanations.

Second, since I do not observe mortgage-holding capacity, I construct two measures as proxies. The first is a direct calculation of the average loan holding period by firm, using hand-collected data from public filings (SEC quarterly and annual 10-Q and 10-K filings, bank “Call Reports,” and securitization

quality underwriting, the focus on this test). Second, if we assume that this channel does play some role, and price effects would offset quality, and so we can interpret the results in Table 5 as net of any price effect. 
prospectuses). ${ }^{27}$ The second measure is the degree to which loans are priced on observable, "hardinformation" loan characteristics such as credit scores and loan-to-value ratios. Rajan et al. (2013) show that, to price and purchase mortgages as the boom progressed, both securitizers and investors of mortgage-backed securities relied increasingly on hard (verifiable) information and less on soft (unverifiable) information about the borrower. ${ }^{28}$ Hard information is easy to observe and contract upon; therefore, mortgages underwritten and priced on hard information could be placed more quickly with third parties in secondary market sales. Consistent with this research, I interpret a firm's greater reliance on hard information for mortgage pricing as a proxy for their intent to sell mortgages quickly on the secondary market. $^{29}$

This proxy — "Pricing R-squared”-is calculated by running one regression per firm of the mortgage price on the contract and macroeconomic characteristics described in equation (1) and extracting the adjusted r-squared. Because of the requirement for sufficient numbers of mortgages and mortgage defaults to calculate both the R-squared and the hazard by lender, only the 241 most active firms could be used for this analysis.

The adjusted R-squared is extracted from running the following model for the $j$ th firm:

$$
\begin{aligned}
\text { price }_{i}= & \alpha_{j}+\beta_{j 1} \text { Macro }_{i} \\
& +\beta_{j 2} \text { Lender }_{i}+\beta_{j 3} \text { Risk }+\beta_{j 4} \text { Contract }_{i}+\beta_{\text {year }} \text { YearFE }_{i}+\beta_{s t} \text { StateFE }_{i}+\varepsilon_{i} .
\end{aligned}
$$

Following Rajan et al. (2013), I use the initial rate of the loan for the price. ${ }^{30}$ The holding-period measure and the explained pricing measure complement each other as proxies: The average loan holding period is subject to an ex post bias since the holding period may increase as loan quality decreases, while the explained pricing measure is unbiased by ex post performance but is, at best, an indirect proxy for capacity constraints.

\subsection{Results}

Table 5a shows the descriptive statistics for the holding-period measures. Overall, the average holding period for homebuilders and standalone mortgage banks is 19.12 and 28.46 days, respectively, and 44.41 and 61.13 days for depository banks and affiliated mortgage lenders. These holding periods are statistically different from each other and consistent with homebuilders and standalone mortgage lenders

\footnotetext{
${ }^{27}$ The details of the data gathered and the holding-period calculation can be provided on request.

${ }^{28}$ Examples of hard information include the controls in equation 1, while unverifiable soft information might include a loan officer's assessment of an applicant's credibility, her future employment prospects and intuition about her likelihood of defaulting.

${ }^{29}$ Another potential interpretation of this proxy is that pricing r-squared represents the degree of soft information available to the lender; however, that would yield the opposite prediction and is not confirmed in the data. I thank an anonymous reviewer for pointing this out.

${ }^{30}$ The results are essentially unchanged when I rerun this analysis with only adjustable-rate mortgages and use the margin charged over the floating index once the teaser period expires.
} 
funded by limited credit lines. Table 5a also shows summary statistics for the Pricing R-squared measure. The reasonably high negative correlation (-0.4071) between the mortgage holding period and pricing Rsquared provides some confirmation that these measures, calculated from different sources and spanning different subsamples, capture similar underlying factors.

\section{$<<$ INSERT TABLE 5 ABOUT HERE $>>$}

Table 5b presents the association between the mortgage holding period and relative default hazard. Column (1) shows the relative hazard by parent affiliations for the subset of firms for which the mortgage holding period was available. This subsample covers $72 \%$ of the mortgages issued for coded (nonmiscellaneous) lenders between 2005 and 2006 and includes public homebuilders and mortgage lenders, federally regulated banks and firms that issued securitizations during the period. ${ }^{31}$ Column (2) shows a significant association between the mortgage holding period and default hazard, with an increase in the holding period from the $10^{\text {th }}$ percentile to the $90^{\text {th }}$ percentile associated with a $28 \%$ increase in default hazard.

Column (3) presents one of the main results of this paper. It includes both holding-period and parent affiliation indicators and shows that the holding period explains the differences in the relative default hazard between lender types. The coefficients on the parent-affiliation indicators are now insignificant, while the coefficient on the mortgage holding period is 1.0064 and significant at the $1 \%$ level. An unreported analysis shows that the reductions in coefficients on the parent affiliation indicators between models (1) and (3) are statistically significant. ${ }^{32}$ Columns (4)-(6) replace the mortgage holding period with the Pricing R-squared measure in the same analysis. ${ }^{33}$ The point estimates and significances on the parent-affiliation indicators are reduced substantially when the Pricing R-Squared proxy is included in the models, although it does not explain all the differences between parent affiliations. ${ }^{34}$

Figure 2 presents results from a related analysis at the firm level, rather than at the individualmortgage level. In this analysis, firm-level measures of lending hazard are calculated by replacing lenderaffiliation indicators with individual lender identifiers in the hazard model for 2005-2006 (as shown in Table 3, Column 3). These firm-level hazard measures are plotted versus the two measures of holding capacity. The results confirm the findings in Table 5. Panel A shows a strong positive association between

\footnotetext{
${ }^{31}$ The sample excludes primarily non-securitizing private standalone lenders and non-federally regulated banks.

${ }^{32}$ Using the suest command with a logit specification, I calculate the significance of the change in the coefficient estimates to have $\operatorname{Pr}>0.0398,0.0223$ and 0.0253 for standalone mortgage lenders, depository banks and affiliated mortgage lenders, respectively.

${ }^{33}$ This second subsample covers $99 \%$ of all coded (non-miscellaneous) lenders, with the bottom $1 \%$ excluded due to insufficient degrees of freedom in the first-stage pricing regression.

${ }^{34}$ Using the suest command with a logit specification, I calculate the significance of the change in the coefficient estimates to be $\operatorname{Pr}>0.6087,0.1004,0.0372$ for standalone mortgage lenders, depository banks and affiliated mortgage lenders, respectively.
} 
the mortgage holding period and firm-level hazard, and Panel B shows a strong negative association between pricing R-squared and firm-level hazard.

\section{$<<$ INSERT FIGURE 2 ABOUT HERE $>>$}

Overall, these analyses show that the differences in default hazard between lenders with different parent affiliations are explained by differences in mortgage-holding capacity, as measured both by mortgage holding periods and by the degree to which loans are priced on hard information. ${ }^{35}$

\subsection{Soft Information}

The second possible explanation for lender differences is that homebuilders possess more "soft" information on the quality of both the borrowers and the local real estate market as a byproduct of the home sales and land purchase process. They then use this information to screen borrowers more diligently, particularly in areas that they anticipate would be more affected by the housing downturn. ${ }^{36}$

This argument implies two sets of predictions. First, the difference in default hazard between homebuilder loans and those from other lenders should be greater within the consumer segments for which soft information is more important for determining default risk-that is, observably riskier consumer segments (Rajan et al. 2013). ${ }^{37}$ Second, the difference in default hazard between homebuilder loans and those from other lenders should be greater in geographies that experienced greater downturns after 2006 (such as Las Vegas, Phoenix and Miami, relative to Houston, for example, which experienced a negligible downturn in 2007). This latter prediction assumes that the broader market did not anticipate the severity of the downturn; therefore, homebuilders' superior local market knowledge would benefit them most in the hardest-hit areas.

\subsubsection{Results}

The results for tests of these two predictions can be found in Table 6. For the tests of superior soft information about homebuyers, I calculate quartiles for three of the most common observable risk

\footnotetext{
35 These results at first may seem hard to reconcile with the high (13.65\%) aggregated default rate of standalone mortgage lenders. The high default rate in Table 1 can be explained by higher concentration of these lenders in riskier geographies and specialization in higher credit risk customers and riskier contract structures. Once these "hard" metrics are accounted for, however, I find that underwriting diligence is higher than depository banks. This finding is consistent with Carey et al (1998) who show that specialized lenders focus on riskier segments and compensate with reputations for tougher underwriting and loan management.

${ }^{36}$ Note that we would have to make additional assumptions about homebuilders' profit functions or secondary market sales to explain why they would choose to apply more diligent screens than their peers, even with free information. For simplicity, we assume that this is the case.

${ }^{37}$ In an unreported analysis, I verified the connection between soft information and observable risk directly by regressing price versus observables by FICO decile and find that the r-squared for the lowest (riskiest) decile is 0.1537, while the r-squared for the highest (least risky) decile is 0.3048 .
} 
measures-FICO score, combined loan-to-value ratio and interest rate-with higher quartiles indicating higher risk. ${ }^{38}$ These quartile indicators are then interacted with the homebuilder affiliate indicator. If homebuilders' use of soft information increases in riskier consumer segments, then the difference in relative hazard between homebuilders and all other lenders should be greater in riskier quartiles (the coefficients on the homebuilder*risk quartile interactions should be less than one and significant for higher-risk quartiles). The results can be seen in Columns (1)-(3). ${ }^{39}$ None of the interaction variables is significant in Columns (1) and (3). In Column (2), the interactions are greater than one and significant, indicating that homebuilder loans were particularly safer in the lowest (safest) quartile of CLTV. While this result is the opposite of our prediction, the interactions in the second, third and fourth quartiles are not significantly different from each other, indicating no clear relationship between risk and decreased relative hazard between homebuilders and financial lenders.

\section{$<<$ INSERT TABLE 6 ABOUT HERE $>>$}

To test for superior local real estate market knowledge, I measure the difference between peak home prices and the subsequent trough post-2006 in each county of the analysis, using the home price index constructed from chained home sales reported in the county deed data. As peak-to-trough distance increases, the difference in relative default hazard between homebuilders and other lenders should increase if homebuilders anticipated the downturn better than their competitors. As with the prior tests, I produce quartiles of the peak-to-trough measure and create interactions with the homebuilder indicator. The results are reported in Column (4). As with the CLTV result in Column (2), the interactions are greater than one and significant, indicating that builder loans were particularly safer in the least-risky geographies. However, also like Column (2), the interactions in the second, third and fourth quartiles are not significantly different from each other, indicating no clear relationship between risk and decreased relative hazard between homebuilders and financial lenders. In short, unlike the prediction for this test, I do not observe any divergence in the hazard ratio between homebuilders and financial lenders as risk quartile increases.

The discussion above must include the caveat that the null results may be a function of the test design and measures used. An ideal test, such as the random assignment of soft information across lenders, did not occur in this context. Conservatively, therefore, the results of these tests do not support soft-information explanations, but they do not rule them out.

\footnotetext{
${ }^{38}$ Consequently, the FICO quartiles are reverse-scored.

39 The difference in the sample size in Column (1) reflects the fact that the FICO score was not available for all mortgages.
} 


\subsection{Foreclosure externalities}

Another explanation for higher lending quality is that homebuilders lent more safely because they internalized the costs of foreclosures within their subdivisions, and other lenders did not. Since World War II, the majority of new homes have been constructed within residential subdivisions that can include thousands of homes (Duany et al. 2000). These subdivisions may require multiple years or decades to sell completely and can have high construction density, so homebuilders assume substantial land and home inventory risk that increases as foreclosures increase in the area. Since financial lenders are not precommitted to subdivisions, they do not internalize these foreclosure costs. The cost of foreclosure externalities has been shown to be quite large: Campbell et al. (2011) estimate a 1\% reduction on the prices of homes within 0.05 miles of a foreclosure and effects up to 0.25 miles.

I develop two predictions based on Campbell et al.’s (2011) result. First, within subdivisions, foreclosures of homes sold earlier in the lifecycle should be costlier to homebuilders than homes sold later since they affect demand and prices on a greater number of future homes. All else equal, therefore, homebuilders should be relatively more diligent with earlier sales than with later sales. This test assumes that homebuilders have foreknowledge of the construction life cycle within a subdivision. ${ }^{40}$ Second, the cost of foreclosures should be relatively greater in more densely constructed subdivisions. Therefore, homebuilders' relative lending diligence should be greater in those subdivisions, while these patterns should not be observed in financial lenders.

To test these predictions, I compute order and density measures using census block groups as a proxy for subdivisions, which cannot be observed. Census block groups are an intermediate measure between census tracts and census blocks, the smallest unit used by the U.S. Census that can map to individual street blocks. These measures are calculated on a pre-merged database of 697,456 loans in order to increase the number of observations within each census block group. ${ }^{41}$ Each zip code contains a median of thirteen census block groups.

I construct a measure of the order of loans issued by the lender in a given census block group over the sample period, normalized from 0 (earliest) to 1 (latest). I then create the density measure as the sum of all mortgages in a census block group for a given lender over the sample period. ${ }^{42}$ Finally, I calculate quartiles of these measures and create interactions with the homebuilder indicator. The prediction is that the differences in relative hazard between homebuilders and financial firms should be

\footnotetext{
40 This assumption seems reasonable in this context since homebuilders' community development plans typically include detailed development schedules of the subdivisions, including multiple development phases that span years and assign sites of future homes to specific phases.

${ }^{41}$ This pre-merged database includes mortgages that include conventional, FHA/VA loans for new construction single family and multifamily homes and condos.

${ }^{42}$ Note this is not a perfect measure of density since not all census block groups are the same geographic size. However, given the exurban composition of the dataset, I assume that it is a reasonable proxy.
} 
greater in earlier and denser quartiles; therefore, the coefficients on the interactions between homebuilder and earlier and denser quartiles should be less than one and significant.

As a robustness test, I also use a subsample of mortgages that includes only homes constructed by homebuilders with lending units. I then recreate order and density measures by construction order and density rather than by lending order and density. This approach arguably controls for more subdivision unobservables in exchange for fewer observations.

\subsubsection{Results}

Table 7 shows the results of these tests. In Column (1), none of the interactions between homebuilder and lending order is significant, suggesting that concern for future foreclosures does not drive safer earlier lending practices by homebuilders. Similarly, in Column (2), the interactions between homebuilder and lending density are significant and greater than one, suggesting that homebuilder loans had the lowest relative default hazard in the least-dense census block groups, the opposite of our prediction. However, the interactions between homebuilder and the second, third and fourth quartiles are not significantly different from each other, indicating that there is not a strong relationship between lending density and lower relative hazard between homebuilders and financial lenders. Column (3) and (4) show no significant interactions between homebuilders and order or density.

\section{$<<$ INSERT TABLE 7 ABOUT HERE $>>$}

Similar to the caveat for the test for soft information, I cannot rule out that the null result in these tests is due to the test design and measures used. One issue is that subdivision density is non-random and unobserved attributes of these subdivisions may cause results that cancel out this test. ${ }^{43}$ An ideal test to identify this channel would involve randomization of the expected costs of foreclosure externalities, potentially by reassigning land and homes under construction within the same subdivision to other developers. These types of treatments are not particularly realistic, but without them, the results of the actual tests performed do not provide causal identification. Conservatively, therefore, they do not support foreclosure externalities as drivers of lending restraint, but they do not rule them out.

\section{Other possible explanations}

There are several other possible explanations for differences between lenders. One possibility is that depository banks were subject to additional regulation requiring them to devote a certain percentage

\footnotetext{
${ }^{43}$ For example, if homebuilder inventory is greater relative to demand in denser subdivisions, then homebuilders may have a greater incentive to screen consumers less diligently in these divisions in order to move inventory.
} 
of their mortgage portfolio to low-income consumers and that these loans drove the differences between banks and other lenders. In fact, the Community Reinvestment Act of 1977 has been shown to lead to poor-quality loans by banks (Agarwal et al. 2012). However, this regulation is unlikely to have influenced the results in this study since the sample consists of high-growth suburban and exurban zip codes that probably did not include many CRA loans. As a check, unreported analysis shows that lending differences do not diminish when excluding the bottom of the home-price distribution, the segment most likely to include CRA loans.

A second possible explanation is that banks and affiliated mortgage banks had access to lowercost funds than other lenders, enabling them to lend to relatively riskier consumers profitably. This explanation, however, is inconsistent with the time history in the federal funds effective rate over the study period. The federal funds effective rate steadily declined from a high of $6.53 \%$ in June 2000 to 0.99\% in March 2004 and then increased from 5.23 to 5.24\% between July 2006 and August 2007. If lower cost of available federal funding to banks drove relatively worse lending, we would expect to see relatively worse bank lending during the earlier period in the sample, followed by a relative increase in banks’ lending standards as the fed funds rate increased in 2004. We observe the opposite.

A third possible explanation is that multiproduct pricing by homebuilders drives differences in loan outcomes. While mortgage/home cross-subsidization is quite plausible in this context, it is unlikely to lead to the results in this paper (i.e., safer homebuilder loans, conditional on observables). First, we would have to believe that homebuilders used the housing operations to subsidize mortgage lending rather than the reverse, which is not plausible in this context. ${ }^{44}$ Second, unreported results show that homebuilders actually offered lower loan rates than financial lenders, which is inconsistent with the multiproduct pricing alternative and consistent with more-conservative screening.

A final possible explanation is that homebuilders show more forbearance than other lenders in filing notices of default. However, given that servicing rights were typically sold at the same time as the mortgage, this explanation would not explain differences in default rates.

\section{Discussion and Conclusion}

This paper shows that loan quality during the years preceding the 2007 housing crisis was, in fact, related to the mortgage lenders' parent affiliation. Lending standards of homebuilders and standalone mortgage lenders deteriorated significantly less than those of depository banks and mortgage lenders affiliated with large financial institutions. This result is surprising for several reasons. It is contrary to prior models and empirical studies of captive finance (Barron et al. 2008; Pierce 2012). Also, both

\footnotetext{
44 That is, we would have to believe that homebuyers would accept lower home sale prices or other in-kind benefits on the home in exchange for worse loan terms and higher loan rates.
} 
homebuilders and standalone mortgage lenders are "originate to distribute” lenders; that is, they originate loans with no intent to retain them on their balance sheets and, therefore, have little "skin in the game." Prior research has suggested that having little skin in the game encouraged lenders to underwrite poorquality loans (Demiroglu and James 2012; Purnanandam 2011).

To understand this result, I investigate three possible explanations and find evidence consistent with one-namely, that lenders with limited mortgage-holding capacity engaged in higher screening than less-constrained lenders. I argue that constrained lenders were particularly affected by market diligence since even a moderate level of mortgage rejections by institutional buyers could absorb already scarce capacity and impair their ability to issue new loans. The analysis supports this explanation: the inclusion of mortgage holding capacity proxies in the main specification is sufficient to explain the default hazard differences between lenders. Furthermore, moving from the $10^{\text {th }}$ to $90^{\text {th }}$ percentile in mortgage-holding capacity is associated with a $28 \%$ increase in loan default hazard. The constraints explanation is also consistent with reported cash flows within homebuilders. As the housing boom progressed, homebuilders allocated relatively more capital to housing operations and less to mortgage units. These cash flow patterns are in turn consistent with practitioner interviews who stated that they allocated as little cash to lending as possible in order to invest as much capital as possible into land and construction during this period. I also investigate whether differences in access to soft information or incentives to avoid foreclosures explain lending quality differences and find no evidence in support of either factor.

This study has several limitations. First, mortgage unit constraints cannot be measured directly, given the diversity of firms and reporting requirements in the sample. Therefore, the study relies on proxies for the analysis. Second, formal causal identification cannot be established: the tests for lending constraints is correlative and so the research design relies on ruling out alternative explanations. This design presents two related challenges: loan quality, interest rates and mortgage holding period may be simultaneously determined by an unobserved factor and therefore the causal chain presented in the paper may not be valid. Also, the null findings from tests of these alternatives may be a function of the tests rather than evidence of the absence of effect in this setting. In fact, it is entirely plausible that multiple factors affecting lending may have been simultaneously present in this setting. Lastly, while the evidence is consistent with the mortgage units' becoming increasingly constrained over time, the available data do not enable a direct test of constraints.

Despite these challenges, the findings of this study have implications for both strategic management and corporate finance. Specifically, the results suggest an interesting relationship among firm boundaries, internal capital markets and strategic adaptation that merits further exploration. I speculate on the relationship as follows: A well-known feature of internal capital markets, as discussed by Stein (1997), is that managers “winner-pick” projects; that is, they direct funds to divisions of their choice 
above levels available from external markets. A necessary, but less-explored, consequence of winnerpicking is what Stein (1997) calls "loser-sticking." That is, to fund winners, managers must withhold funds from other projects, even if those projects are NPV-positive and would otherwise be funded by external markets. Since firm boundaries define the set of projects that are ranked relative to each other, boundaries influence whether a business unit (equivalent to a project for this discussion) is well-funded or resource constrained. Resource constraints, in turn, drive different behavior in end markets, including how firms adapt to shifts in the external environment.

In this study, although the association cannot be observed directly, evidence from public homebuilders' cash-flow statements supports the idea that mortgage units were "loser-stuck" during this period: As the housing boom progressed, the mortgage units received a decreasing proportion of cash relative to the housing operations. Furthermore, unreported analyses show that mortgage units received a lower share of cash relative to housing operations as homebuilders' revenue and earnings increased. I propose that, as the boom progressed and these units received fewer resources, they responded by exerting relatively more diligence than their less-constrained financial counterparts.

The findings of this paper suggest a larger research agenda on the effects of firm scope on internal capital and labor markets. To the extent that we can interpret looser diligence as evidence of agency problems within firms, then loser-sticking may mitigate these issues by exposing firms to greater market discipline. Aside from greater discipline, loser-sticking may have other consequences for firm adaption. For example, it may influence how these secondary units innovate, choose their product lines or otherwise respond to competition. Firm scope may also have effects on internal labor markets analogous to those on capital markets, with "loser" units attracting different talent than would be available to otherwise identical non-integrated units, or "winner” units, in different firms. Winner-picking may also have similar-magnitude effects on adaptation.

In sum, this research proposes a different approach to Coase (1937)'s question on the nature of firms and markets. By applying the concept of "winners" and "losers” in internal capital (or labor) markets to organizational strategy, the paper speculates that firm boundaries matter because they affect not only transaction costs and property rights, but also resource endowments. Given the primary focus of this research on explaining the main empirical result of lending differences between firms, confirmation of this proposition is left for future research. 


\section{References}

Agarwal, Sumit, Effi Benmelech, Nittai Bergman and Amit Seru, 2012, Did the Community Reinvestment Act (CRA) lead to risky lending?, NBER working paper w18609.

Barron, John, Andrew Chong and Michael Staten, 2008, The emergence of captive finance companies and risk segmentation of the consumer loan market: theory and evidence, Journal of Money, Credit and Banking, Vol. 40, Issue 1.

Baysinger Barry and Robert E Hoskisson, 1989, Diversification strategy and R\&D intensity in multiproduct firms, Academy of Management Journal, Vol. 32, No. 2.

Bolton, Patrick and David Scharfstein, 1998, Corporate finance, the theory of the firm, and organization, Journal of Economic Perspectives, Vol. 12, No. 4.

Campbell, John, Stefano Giglio and Parag Pathak, 2011, Forced sales and house prices, American Economic Review, Vol. 101, No. 5.

Carey, Mark, Mitch Post and Steven Sharpe, 1998, Does corporate lending by banks and finance companies differ? Evidence on specialization in private debt contracting, The Journal of Finance, Vol. 53, No. 3.

Coase, Ronald, 1937. The Nature of the Firm, Economica, Vol. 4, No. 16.

Dell'Ariccia, Giovanni, Deniz Igan and Luc Laeven, 2012, Credit booms and lending standards: Evidence from the subprime mortgage market, Journal of Money, Credit and Banking, Vol. 44, No. 2-3.

Demiroglu, Cem and Christopher James, 2012, How Important is Having Skin in the Game? OriginatorSponsor Affiliation and Losses on Mortgage-backed Securities, Review of Financial Studies, Vol. 25, No. 11.

Demyanyk, Yuliya and Otto Van Hemert, 2011, Understanding the subprime mortgage crisis, Review of Financial Studies, Vol 24, No 6.

Donaldson, Gordon, 1984. Managing Corporate Wealth, Praeger Publishers, NY.

Duany, Andres, Elizabeth Plater-Zyberk and Jeff Speck, 2001, Suburban Nation: The Risk of Sprawl and the Decline of the American Dream, North Point Press.

Foote, Christopher, Kristopher Gerardi, Lorenz Goette and Paul Willen, 2008a, Just the facts: An initial analysis of subprime's role in the housing crisis, Journal of Housing Economics, Vol 17, Issue 4.

Forbes, Silke and Mara Lederman, 2009, Adaptation and vertical integration in the airline industry, American Economic Review, Vol. 99, No 5.

Hart, Oliver and Bengt Holmstrom, 2010, A theory of firm scope, Quarterly Journal of Economics, Vol. 125, No. 2. 
Henderson, Rebecca and Ian Cockburn, 1996, Scale, scope and spillovers: the determinants of research productivity in drug discovery, Rand Journal of Economics, Vol. 27.

Hoskisson, Robert E, Michael A Hitt and Charles W L Hill, 1993, Managerial incentives and investment in R\&D in large multiproduct firms, Organization Science, Vol. 4, No. 2.

Keys, Benjamin, Tanmoy Mukherjee, Amit Seru and Vikrant Vig, 2009, Financial regulation and securitization: evidence from subprime loans, Journal of Monetary Economics, Vol. 56 Issue 5.

Keys, Benjamin, Tanmoy Mukherjee, Amit Seru and Vikrant Vig, 2010, Did securitization lead to lax screening: Evidence from subprime loans, Quarterly Journal of Economics, Vol 125, No 1.

Kogut, Bruce and Udo Zander, 1992, Knowledge of the firm, combinative capabilities, and the replication of technology, Organization Science, Vol. 3, No. 3.

Lamont, Owen, 1997, Cash flow and investment: Evidence from internal capital markets, Journal of Finance, Vol. 52, No. 1.

Lyandres, Evgeny, 2006, Strategic cost of diversification, Review of Financial Studies, Vol. 20, No. 6.

Macher, Jeffrey, 2006, Technological development and the boundaries of the firm: A knowledge-based examination in semiconductor manufacturing, Management Science, Vol. 52, No. 6.

Mayer, Christopher, Karen Pence and Shane Sherlund, 2009, The rise in mortgage defaults, Journal of Economic Perspectives, Vol 23, No 1, 27-50.

Mian, Atif and Amir Sufi, 2009, The consequences of mortgage credit expansion: Evidence from the U.S. mortgage default crisis, Quarterly Journal of Economics, Vol. 124, No 4.

Novak, Sharon and Scott Stern, 2008, How does outsourcing affect performance dynamics? Evidence from the automobile industry, Management Science, Vol. 54, No. 12.

Nickerson, Jackson and Todd Zenger, 2004, A knowledge-based theory of the firm - The problemsolving perspective, Organization Science, Vol. 15, No 6.

Nickerson, Jackson and Todd Zenger, 2008, Envy, comparison costs, and the economic theory of the firm, Strategic Management Journal, Vol. 29, No 13.

Ozbas, Oguzhan and David Scharfstein, 2010, Evidence on the dark side of internal capital markets, Review of Financial Studies, Vol. 23, No. 2.

Pierce, Lamar, 2012, Organizational structure and the limits of knowledge sharing: incentive conflict and agency in car leasing, Management Science, Vol 58, No. 6.

Piskorski, Tomasz, Amit Seru and Vikrant Vig, 2010, Securitization and distressed loan renegotiation: Evidence from the subprime mortgage crisis, Journal of Financial Economics, Vol. 93, No. 3.

Purnanandam, Amiyatosh, 2011, Originate-to-distribute model and the subprime mortgage crisis, Review of Financial Studies, Vol 24. 
Rajan, Raghuram, Henri Servaes and Luigi Zingales, 2000, The cost of diversity: The diversification discount and inefficient investment, Journal of Finance, Vol. 55, No. 1.

Rajan, Uday, Amit Seru and Vikrant Vig, 2013, The failure of models that predict failure: distance, incentives and defaults, Journal of Financial Economics, forthcoming.

Rawley, Evan and Timothy Simcoe, 2010, Diseconomies of scope and vertical contracting: evidence from the taxicab industry, Management Science, Vol. 56, No. 9.

Rawley, Evan , 2010, Diversification, coordination costs, and organizational rigidity: Evidence from microdata, Strategic Management Journal, Vol. 31, No. 8.

Remolona, Eli M., and Kurt C.Wulfekuhler, 1992, Finance Companies, Bank Competition, and Niche Markets. The Federal Reserve Bank of New York, Quarterly Review, Summer,25-38.

Scharfstein, David and Jeremy Stein, 2000, The dark side of internal capital markets: Divisional rentseeking and inefficient investment, Journal of Finance, Vol. 55, No. 6.

Seru, Amit, 2013, Firm boundaries matter: Evidence from conglomerates and R\&D activity, Journal of Financial Economics, forthcoming.

Shiller, Robert, 2008. The Subprime Solution: How Today's Global Financial Crisis Happened, and What to Do about It, Princeton University Press.

Stein, Jeremy, 1997. Internal Capital Markets and the Competition for Corporate Resources, Journal of Finance, Vol. 52, No. 1.

Williamson, Oliver, 1975, Markets and hierarchies, analysis and antitrust implications, New York: Macmillan.Chandler 1990

Zhou, Maggie Yue, 2011, Synergy, Coordination Costs and Diversification Choices, Strategic Management Journal, Vol. 32, No. 6. 
Figure 1a: Market share of new home purchase mortgages lender type by year.

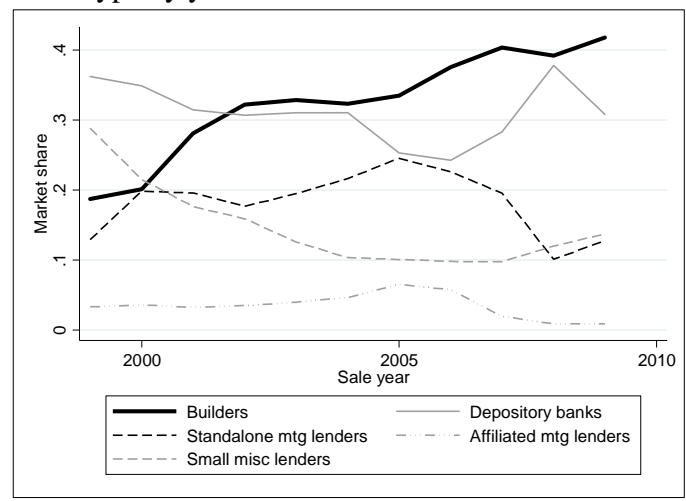

Figure 1b: Number of new home purchase mortgages underwritten by each lender type by year.

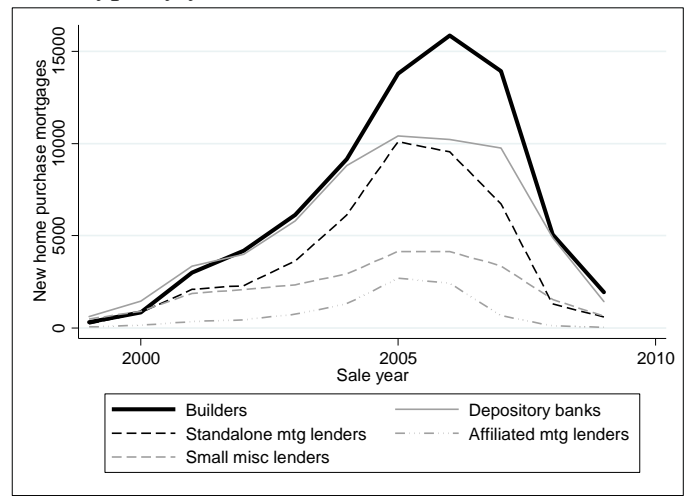

Figure 2: Firm-level hazard of mortgage default by measures of mortgage holding period.
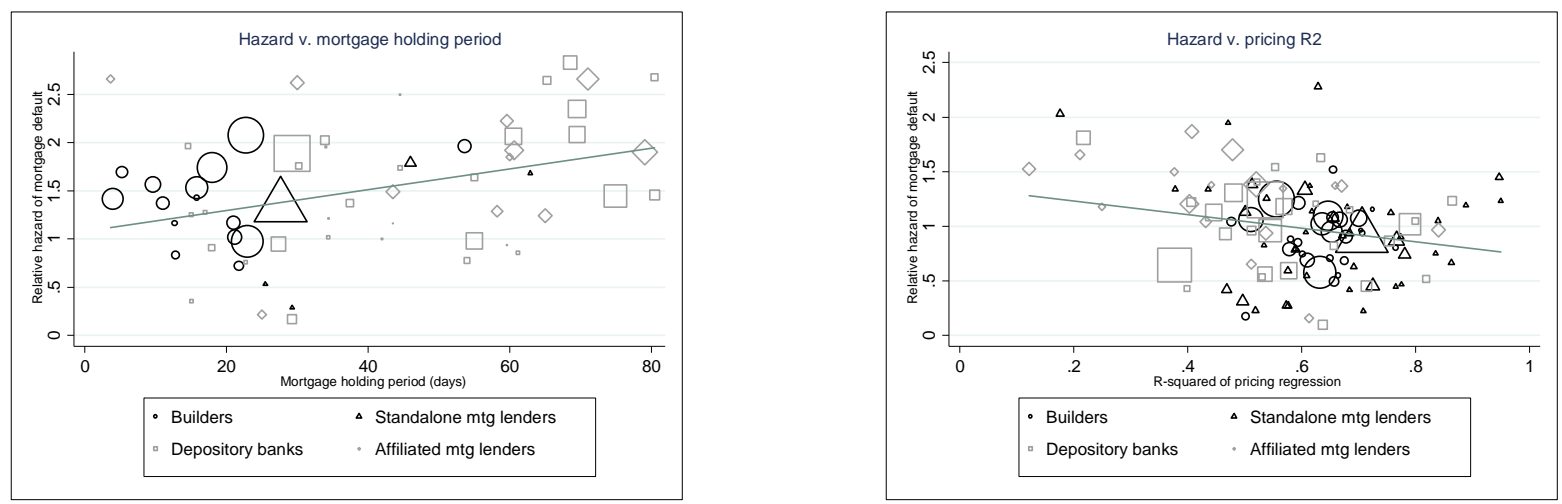

Notes: See Table 5a for mortgage holding descriptive statistics. The left-hand figure shows hazard versus calculated mortgage holding period. The right-hand figure shows hazard versus the r-squared of a firm-by-firm regression of pricing on observable mortgage characteristics (see equation 2). Hazard is calculated by extracting the coefficient on a firm dummy in a specification that replaces firm dummies for lender type dummies in equation 1. 
Table 1: Descriptive statistics.

\begin{tabular}{|c|c|c|c|c|c|}
\hline & $\begin{array}{l}\text { Homebuilders } \\
n=74,262\end{array}$ & $\begin{array}{l}\text { Standalone } \\
\text { mtg lenders } \\
n=44,550\end{array}$ & $\begin{array}{l}\text { Depository } \\
\text { banks } \\
n=60,657\end{array}$ & $\begin{array}{l}\text { Affiliated } \\
\text { mtg lenders } \\
n=8,087\end{array}$ & $\begin{array}{l}\text { Small misc } \\
n=24,502\end{array}$ \\
\hline \multicolumn{6}{|l|}{ Mortgage amounts and prices } \\
\hline Sale amt (\$) & 281,602 & 288,060 & 296,932 & 280,088 & 277,779 \\
\hline Mtg amt (\$) & 213,353 & 220,912 & 226,681 & 215,453 & 213,428 \\
\hline Initial interest rate (\%) & 6.10 & 6.15 & 6.04 & 7.19 & 6.30 \\
\hline Reset spread (\%) & 2.56 & 3.14 & 2.78 & 5.25 & 3.32 \\
\hline \multicolumn{6}{|l|}{ Borrower observable risk } \\
\hline CLTV (\%) & 80.64 & 83.35 & 82.98 & 86.27 & 82.45 \\
\hline FICO & 723 & 707.8 & 710.9 & 656.3 & 708 \\
\hline Low or no documentation (\%) & 56.62 & 67.99 & 36.01 & 49.65 & 51.85 \\
\hline Back-end DTI & 18.66 & 25.24 & 15.66 & 15.14 & 15.97 \\
\hline \multicolumn{6}{|l|}{ Product type } \\
\hline $\mathrm{ADJ}(\%)$ & 11.65 & 17.27 & 20.98 & 27.96 & 16.42 \\
\hline Fix (\%) & 76.53 & 63.66 & 67.19 & 32.56 & 75.09 \\
\hline Hyb (\%) & 11.43 & 17.49 & 8.94 & 20.08 & 5.86 \\
\hline Bal (\%) & 0.39 & 1.58 & 2.9 & 19.4 & 2.63 \\
\hline \multicolumn{6}{|l|}{ Contract terms } \\
\hline Negative amortization (\%) & 5.44 & 14.76 & 7.77 & 1.6 & 9.22 \\
\hline Interest only (\%) & 21.96 & 27.35 & 17.65 & 34.95 & 16.1 \\
\hline Prepayment penalty (\%) & 5.45 & 22.04 & 13.59 & 50.89 & 17.65 \\
\hline \multicolumn{6}{|l|}{ Geographic distribution } \\
\hline \% loans from bubble states (AZ, CA, FL, NV) & 57.79 & 43.56 & 50.88 & 49.93 & 41.77 \\
\hline \multicolumn{6}{|l|}{ Loan Performance } \\
\hline Notice of default (\%) & 7.86 & 13.65 & 7.89 & 21.76 & 9.2 \\
\hline \multicolumn{6}{|l|}{ Lender characteristics } \\
\hline Log annual number loans & 2,833 & 2,994 & 1,766 & 440 & 111 \\
\hline Lender independent (\%) & 0 & 98.63 & 59.03 & 3.98 & 100 \\
\hline Parent public (\%) & 92.01 & 38.7 & 96.54 & 86.84 & 0 \\
\hline Lender JV with bank (\%) & 14.96 & & & & \\
\hline
\end{tabular}

Notes: See Appendix A for variable definitions 
Table 2: Hazard of mortgage default, 1999-2009

\begin{tabular}{|c|c|c|c|c|}
\hline \multirow[b]{2}{*}{$\begin{array}{l}\text { Dependent variable: } \\
\text { Mortgage default }\end{array}$} & \multicolumn{4}{|c|}{ Hazard Ratio } \\
\hline & $\begin{array}{l}\text { Unconditional } \\
(1)\end{array}$ & $\begin{array}{l}\text { Geo only } \\
(2)\end{array}$ & $\begin{array}{l}\text { Geo, risk, } \\
\text { contract } \\
(3) \\
\end{array}$ & $\begin{array}{l}\text { Geo, risk, } \\
\text { contract, pricing } \\
\text { (4) }\end{array}$ \\
\hline \multicolumn{5}{|l|}{ Parent Affiliation } \\
\hline Standalone mortgage lenders & $\begin{array}{l}1.5672 * * \\
(2.0680)\end{array}$ & $\begin{array}{l}2.6829 * * * \\
(4.1683)\end{array}$ & $\begin{array}{l}1.2519 * \\
(1.8884)\end{array}$ & $\begin{array}{l}1.1984 * \\
(1.7730)\end{array}$ \\
\hline Depository banks & $\begin{array}{l}0.9784 \\
(-0.1301)\end{array}$ & $\begin{array}{l}2.1385^{* * *} \\
(3.4760)\end{array}$ & $\begin{array}{l}1.3586 * * * \\
(2.8779)\end{array}$ & $\begin{array}{l}1.3317^{* * *} \\
(2.9521)\end{array}$ \\
\hline Affiliated mortgage lenders & $\begin{array}{l}2.5427 * * * \\
(5.0992)\end{array}$ & $\begin{array}{l}3.9879 * * * \\
(8.2475)\end{array}$ & $\begin{array}{l}1.6538 * * * \\
(5.6750)\end{array}$ & $\begin{array}{l}1.5155^{* * *} \\
(4.7852)\end{array}$ \\
\hline Misc lenders & $\begin{array}{l}1.0749 \\
(0.4656)\end{array}$ & $\begin{array}{l}2.4814 * * * \\
(3.7494)\end{array}$ & $\begin{array}{l}1.4077 * * \\
(2.3117)\end{array}$ & $\begin{array}{l}1.3587 * * \\
(2.1966)\end{array}$ \\
\hline $\begin{array}{l}\text { Mortgage amount } \\
\text { Log mortgage amt }\end{array}$ & & & $\begin{array}{l}1.4738 * * * \\
(13.9356)\end{array}$ & $\begin{array}{l}1.5338 * * * \\
(16.7742)\end{array}$ \\
\hline $\begin{array}{l}\text { Borrower observable risk } \\
\text { CLTV }\end{array}$ & & & $\begin{array}{l}58.9151^{* * *} \\
(24.4874)\end{array}$ & $\begin{array}{l}50.5540 * * * \\
(24.4020)\end{array}$ \\
\hline Origination FICO & & & $\begin{array}{l}0.9938 * * * \\
(-20.1116)\end{array}$ & $\begin{array}{l}0.9945^{* * *} \\
(-15.6915)\end{array}$ \\
\hline Low or no doc flag & & & $\begin{array}{l}1.5355^{* * *} \\
(9.2688)\end{array}$ & $\begin{array}{l}1.4651^{* * *} \\
(9.1644)\end{array}$ \\
\hline Back-end DTI & & & $\begin{array}{l}1.0011 \\
(1.0933)\end{array}$ & $\begin{array}{l}1.0017^{*} \\
(1.7962)\end{array}$ \\
\hline $\begin{array}{l}\text { Product type } \\
\text { Fixed rate mtg }\end{array}$ & & & $\begin{array}{l}0.7209 * * * \\
(-5.7366)\end{array}$ & $\begin{array}{l}0.1209 * * * \\
(-7.9220)\end{array}$ \\
\hline $\begin{array}{l}\text { Contract terms } \\
\text { Negam flag }\end{array}$ & & & $\begin{array}{l}1.2530 * * \\
(2.4901)\end{array}$ & $\begin{array}{l}1.9955^{* * *} \\
(8.8159)\end{array}$ \\
\hline IO flag & & & $\begin{array}{l}1.2172 * * * \\
(4.1579)\end{array}$ & $\begin{array}{l}1.1957 * * * \\
(3.9078)\end{array}$ \\
\hline Prepay flag & & & $\begin{array}{l}1.1597 * * \\
(2.4579)\end{array}$ & $\begin{array}{l}1.0985^{* *} \\
(2.1272)\end{array}$ \\
\hline $\begin{array}{l}\text { Pricing } \\
\text { Initial interest rate }\end{array}$ & & & & $\begin{array}{l}1.1209 * * * \\
(7.1847)\end{array}$ \\
\hline Fixed rate mtg*initial rate & & & & $\begin{array}{l}1.3241 * * * \\
(12.9751)\end{array}$ \\
\hline Margin over ARM index & & & & $\begin{array}{l}0.9925 \\
(-0.5814)\end{array}$ \\
\hline \multicolumn{5}{|l|}{ Macroeconomic characteristics } \\
\hline Log tract 2000 med inc & & $\begin{array}{l}0.6486 * * * \\
(-6.1155)\end{array}$ & $\begin{array}{l}0.6837 * * * \\
(-7.0098)\end{array}$ & $\begin{array}{l}0.6854 * * * \\
(-6.7972)\end{array}$ \\
\hline Freddie 30-year rate & & $\begin{array}{l}0.9466 \\
(-1.4470)\end{array}$ & $\begin{array}{l}1.0501 \\
(1.2427)\end{array}$ & $\begin{array}{l}0.9110 * * \\
(-2.0974)\end{array}$ \\
\hline Fed funds rate & & $\begin{array}{l}1.2437 * * * \\
(6.7046)\end{array}$ & $\begin{array}{l}1.1861^{* * *} \\
(5.3268)\end{array}$ & $\begin{array}{l}1.1570 * * * \\
(4.8952)\end{array}$ \\
\hline
\end{tabular}


Regional home prices

State-level unemployment

Lender characteristics

Log annual num loans

$\begin{array}{lll}1.0045 & 0.9772 & 0.9850\end{array}$

Lender is independent

(0.1074) (-0.9328)

$(-0.6531)$

0.7822

0.9730

0.9708

Public parent flag

$(-1.3412)$

$(-0.2613)$

$(-0.3395)$

1.3847

1.1063

1.0123

(1.2598)

(0.6897)

(0.0849)

Log parent assets

0.9748

0.9895

0.9940

$(-1.2825) \quad(-0.8744)$

$(-0.5097)$

Lender is bank JV

1.3052

$0.8243 * * *$

$0.8334 * * *$

(1.2743)

$(-3.0465)$

$(-2.8400)$

\begin{tabular}{lllll}
\hline Year FE & N & Y & Y & Y \\
State FE & N & Y & Y & Y \\
\hline Observations & 211,551 & 211,551 & 211,551 & 211,551 \\
\hline Pseudo R-squared & 0.003 & 0.067 & 0.090 & 0.092 \\
\hline
\end{tabular}

Notes: This table compares the hazard of default of mortgages issued by lender type, with homebuilders the omitted category. Column (1) compares unconditional hazard; Column (2) adds state and origination year fixed effects, lender and macroeconomic controls; Column (3) adds hard risk metrics and mortgage characteristics; and Column (4) adds pricing data. See Appendix A for variable definitions. Coefficient estimates are expressed as exponentiated (non-negative) hazard ratios, with $t$-statistics reported below in (). ( $t$ statistics are negative when the hazard ratio is less than one.) All errors are clustered by lender. ***, **, * significant at 1 , 5 , and $10 \%$ level. 
Table 3: Hazard of mortgage default by time period.

\begin{tabular}{|c|c|c|c|c|}
\hline \multirow{3}{*}{$\begin{array}{l}\text { Dependent variable: } \\
\text { Mortgage default }\end{array}$} & \multicolumn{4}{|c|}{ Hazard Ratio } \\
\hline & 1999-2002 & 2003-2004 & 2005-2006 & 2007-2009 \\
\hline & $(1)$ & (2) & (3) & (4) \\
\hline \multirow{2}{*}{ Standalone mortgage lenders } & 1.0887 & 1.0623 & 1.1401 & $1.5023^{* *}$ \\
\hline & $(0.3290)$ & $(0.3849)$ & $(1.2348)$ & $(2.1561)$ \\
\hline \multirow{2}{*}{ Depository banks } & 1.1917 & 0.9968 & $1.3582^{* * *}$ & $1.4641^{* *}$ \\
\hline & $(0.7791)$ & $(-0.0179)$ & (3.1618) & $(2.3605)$ \\
\hline \multirow{2}{*}{ Affiliated mortgage lenders } & 0.9185 & 1.2590 & $1.5643^{* * *}$ & 1.3338 \\
\hline & $(-0.3786)$ & (1.3555) & (4.7859) & (1.3179) \\
\hline \multirow{2}{*}{ Misc lenders } & 1.0303 & 1.1416 & $1.3359 * *$ & $1.7956^{*}$ \\
\hline & $(0.0823)$ & $(0.3972)$ & $(2.0772)$ & (1.7882) \\
\hline Observations & 29,593 & 46,830 & 83,201 & 51,920 \\
\hline Pseudo R-squared & 0.085 & 0.075 & 0.069 & 0.081 \\
\hline
\end{tabular}

Notes: This table examines the relative hazard of mortgage default over time, with homebuilders as the omitted category. All models include geographic, risk, contract and pricing controls from Table 2, Column (4), as well as state and year fixed effects. See Appendix A for variable definitions. Coefficient estimates are expressed as exponentiated (non-negative) hazard ratios, with $t$-statistics reported below in (). (t-statistics are negative when the hazard ratio is less than one.) All errors are clustered by lender. ***, **, * significant at 1,5 , and $10 \%$ level. 
Table 4: Median housing (land purchase, improvement and construction) cash flows relative to mortgage unit

\begin{tabular}{cccc} 
& $\begin{array}{c}\text { Median housing cash flow / } \\
\text { firm net income }\end{array}$ & $\begin{array}{c}\text { Median mortgage unit cash } \\
\text { flow / firm net income }\end{array}$ & $\begin{array}{c}\text { Median mortgage unit cash flow } \\
\text { / housing cash flow }\end{array}$ \\
\hline All years & 1.2697 & 0.0348 & 0.0518 \\
\hline 1999 & 1.3519 & 0.2569 & 0.1198 \\
2000 & 1.5346 & 0.0681 & 0.0534 \\
2001 & 0.8864 & 0.3239 & 0.2164 \\
2002 & 0.8600 & 0.3276 & 0.3573 \\
2003 & 0.8933 & 0.0572 & 0.0658 \\
2004 & 1.1886 & 0.0300 & 0.0018 \\
2005 & 1.4419 & 0.0388 & 0.0349 \\
2006 & 1.9384 & 0.0696 & 0.0432 \\
2007 & -0.3169 & 0.0000 & -0.0887 \\
2008 & - & - & - \\
2009 & - & - & - \\
\hline
\end{tabular}

Note: Cash flow / net income is calculated as a two-year rolling measure and is set to 0 for negative net income years (therefore, 0 for all firms in 2008 and 2009). Data includes all public homebuilders for which information was available in 10-K filings: Centex, DR Horton, Hovnanian, Lennar, MDC, Pulte, Standard Pacific and Tousa. Top column is not two-year smoothed, but annual calculations. 
Table 5: Mortgage-holding capacity and hazard of mortgage default Panel A: Descriptive statistics

\begin{tabular}{|c|c|c|c|c|}
\hline & Homebuilders & $\begin{array}{c}\text { Standalone mortgage } \\
\text { lenders }\end{array}$ & Depository banks & $\begin{array}{c}\text { Affiliated } \\
\text { mortgage lenders }\end{array}$ \\
\hline \multicolumn{5}{|c|}{ Mortgage holding period } \\
\hline Mean (days) & 19.12 & 28.46 & 44.41 & 61.13 \\
\hline St dev & 8.65 & 3.82 & 20.02 & 18.14 \\
\hline \# (firms) & 15 & 5 & 42 & 15 \\
\hline \multicolumn{5}{|l|}{ Pricing R-squared } \\
\hline Mean & 0.61 & 0.67 & 0.53 & 0.49 \\
\hline St dev & 0.06 & 0.11 & 0.14 & 0.17 \\
\hline \# (firms) & 29 & 114 & 79 & 37 \\
\hline
\end{tabular}

Panel B: Hazard of mortgage default, 2005-2006

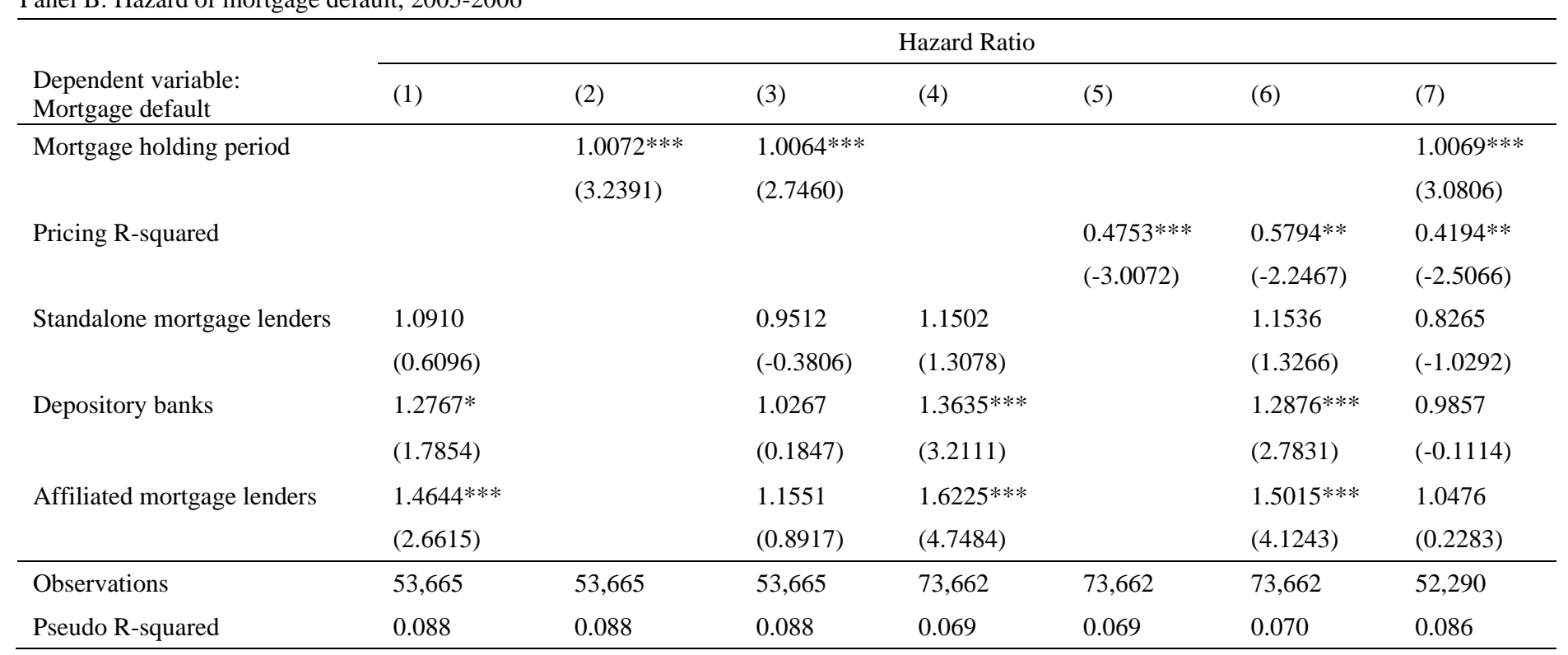

Notes: "Miscellaneous lenders" category has been omitted because no data could be gathered on these lenders for this analysis. All models include geographic, risk, contract and pricing controls from Table 2, Column (4), as well as state and year fixed effects. See Appendix A for variable definitions. Coefficient estimates are expressed as exponentiated (non-negative) hazard ratios, with $t$-statistics reported below in (). ( $t$-statistics are negative when the hazard ratio is less than one.) All errors are clustered by lender. ***, **, * significant at 1,5 , and $10 \%$ level. 
Table 6: Information tests

\begin{tabular}{|c|c|c|c|c|}
\hline \multirow{4}{*}{$\begin{array}{l}\text { Dependent variable: } \\
\text { Mortgage default } \\
\text { Risk measure: }\end{array}$} & \multicolumn{4}{|c|}{ Hazard Ratio } \\
\hline & \multicolumn{3}{|l|}{ Customer } & \multirow{3}{*}{$\begin{array}{l}\text { Geography } \\
\text { Peak to trough } \\
\text { (4) }\end{array}$} \\
\hline & FICO & CLTV & Interest rate & \\
\hline & $(1)$ & $(2)$ & (3) & \\
\hline \multirow[t]{2}{*}{ Homebuilder } & $0.7106^{* * *}$ & $0.3729 * * *$ & $0.6542 * * *$ & $0.4642 * * *$ \\
\hline & $(-2.9753)$ & $(-6.0065)$ & $(-3.1998)$ & $(-4.2783)$ \\
\hline \multirow[t]{2}{*}{ Homebuilder*second quartile } & 0.9890 & $1.7418 * * *$ & 1.0546 & $1.3961 * *$ \\
\hline & $(-0.2045)$ & $(4.8769)$ & $(0.9600)$ & $(2.0904)$ \\
\hline \multirow[t]{2}{*}{ Homebuilder*third quartile } & 1.0338 & $1.8280 * * *$ & 1.0717 & $1.5771 * * *$ \\
\hline & $(0.5693)$ & $(5.5969)$ & $(1.1892)$ & $(3.0437)$ \\
\hline \multirow[t]{2}{*}{ Homebuilder*top quartile (most risky) } & 1.0658 & $1.8742 * * *$ & 0.9520 & $1.4511^{* *}$ \\
\hline & $(0.4753)$ & $(5.2421)$ & $(-0.4328)$ & $(2.1663)$ \\
\hline \multirow[t]{2}{*}{ Second quartile } & $1.5699 * * *$ & $1.3320 * * *$ & 0.9346 & $1.3129 * * *$ \\
\hline & $(13.8014)$ & (4.5173) & $(-1.4814)$ & (3.6666) \\
\hline \multirow[t]{2}{*}{ Third quartile } & $1.9029 * * *$ & $1.9943 * * *$ & $1.2444 * * *$ & $2.7452 * * *$ \\
\hline & $(14.8604)$ & $(9.8727)$ & $(4.2615)$ & (13.1953) \\
\hline \multirow[t]{2}{*}{ Top quartile (most risky) } & $2.5391 * * *$ & $3.0934 * * *$ & $2.0622 * * *$ & $2.7414 * * *$ \\
\hline & $(13.5234)$ & $(17.2388)$ & $(8.2427)$ & $(12.2932)$ \\
\hline Observations & 72,052 & 83,201 & 83,201 & 83,201 \\
\hline Pseudo R-squared & 0.067 & 0.064 & 0.064 & 0.061 \\
\hline
\end{tabular}

Notes: FICO quartiles are reverse-scored, so that Top quartile refers to the lowest (riskiest) quartile of FICO scores. Peak to trough is a measure of the difference between the peak home prices in a given county and the subsequent trough, from home price indices calculated by the author by using chained sales within each county in the dataset. Column (1) excludes mortgages with missing FICO scores. All models include geographic, risk, contract and pricing controls from Table 2, Column (4), as well as state and year fixed effects. See Appendix A for variable definitions. Coefficient estimates are expressed as exponentiated (non-negative) hazard ratios, with $t$-statistics reported below in (). (t-statistics are negative when the hazard ratio is less than one.) All errors are clustered by lender. $* * *, * *, *$ significant at 1,5 , and $10 \%$ level. 
Table 7: Foreclosure externality tests by quartile

\begin{tabular}{|c|c|c|c|c|}
\hline & \multicolumn{4}{|l|}{ Hazard Ratio } \\
\hline & $\begin{array}{l}\text { Lending order } \\
\text { (reverse-coded) } \\
\text { (1) }\end{array}$ & $\begin{array}{l}\text { Lending density } \\
\text { (2) }\end{array}$ & $\begin{array}{l}\text { Construction order } \\
\text { (reverse-coded) } \\
\text { (3) }\end{array}$ & $\begin{array}{l}\text { Construction } \\
\text { density } \\
(4)\end{array}$ \\
\hline \multirow[t]{2}{*}{ Homebuilder } & $0.7686^{* * *}$ & $0.5523 * * *$ & $0.6638 * * *$ & $0.6449 * * *$ \\
\hline & $(-3.0622)$ & $(-3.1973)$ & $(-4.4360)$ & $(-5.2676)$ \\
\hline \multirow[t]{2}{*}{ Homebuilder*second quartile } & 0.9142 & $1.3796^{*}$ & 0.9907 & 1.0770 \\
\hline & $(-1.5310)$ & $(1.8183)$ & $(-0.1505)$ & $(0.7595)$ \\
\hline \multirow[t]{2}{*}{ Homebuilder*third quartile } & 0.9190 & $1.5078 * *$ & 1.0249 & 1.0320 \\
\hline & $(-1.1876)$ & $(2.3464)$ & $(0.3990)$ & $(0.4710)$ \\
\hline \multirow[t]{2}{*}{ Homebuilder*top quartile (most externalities) } & 0.9242 & $1.4922 * *$ & 1.0983 & 1.0369 \\
\hline & $(-0.8958)$ & $(2.1267)$ & $(1.2019)$ & $(0.3355)$ \\
\hline \multirow[t]{2}{*}{ Second quartile } & 1.0302 & $0.8969 * *$ & 0.9609 & $1.1204 *$ \\
\hline & $(0.8758)$ & $(-2.4448)$ & $(-0.9941)$ & (1.7678) \\
\hline \multirow[t]{2}{*}{ Third quartile } & 1.0463 & $0.8476^{* *}$ & 0.9498 & 0.9227 \\
\hline & $(1.0270)$ & $(-2.2910)$ & $(-1.4379)$ & $(-1.6301)$ \\
\hline \multirow[t]{2}{*}{ Top quartile (most externalities) } & 1.0708 & $0.7314^{* * *}$ & 0.9754 & 0.9479 \\
\hline & $(0.9948)$ & $(-5.1679)$ & $(-0.5155)$ & $(-1.0334)$ \\
\hline Observations & 82,996 & 82,996 & 51,294 & 51,294 \\
\hline Pseudo R-squared & 0.069 & 0.069 & 0.072 & 0.072 \\
\hline
\end{tabular}

Notes: Lending order refers to the order of loans issued by a lender within a census block group (as a measure of future foreclosure risk), and has been reverse-coded so that higher quartiles refer to earlier lending (and, hence, greater potential externalities). Lending density refers to the number of loans by a given lender within a census block group (a measure of loans exposed to foreclosure costs). Construction order refers to the order of construction by a homebuilder within a census block group (as a measure of future foreclosure risk), and has been reverse-coded so that higher quartiles refer to earlier construction (and, hence, greater potential externalities). Construction density refers to the number of homes constructed by a homebuilder within a census block group (measure of number of homes exposed to foreclosure costs). Specifications using these measures include only homes constructed by homebuilders with in-house lenders and compare in-house loans versus loans made by outside lenders. All models include geographic, risk, contract and pricing controls from Table 2, Column (4), as well as state and year fixed effects and include mortgages issued between 2005 and 2006. See Appendix A for variable definitions. Coefficient estimates are expressed as exponentiated (non-negative) hazard ratios, with t-statistics reported below in (). ( $t$-statistics are negative when the hazard ratio is less than one.) All errors are clustered by lender. ***, **, * significant at 1,5 , and $10 \%$ level. 


\section{Appendix A -- Variable definitions}

\begin{tabular}{|c|c|c|}
\hline Variable & Definition & Source \\
\hline Notice of default & $\begin{array}{l}\text { A notice filed in the county public record that the borrower has } \\
\text { officially defaulted on the mortgage. This notice is considered } \\
\text { the first step in foreclosure proceedings. }\end{array}$ & Public records \\
\hline Sale amt (\$) & Sale price appearing on the recording document & Public records \\
\hline Mtg amt (\$) & Amount of the mortgage, first-lien only & Public records \\
\hline Initial interest rate & Original or initial interest rate as of the loan's first payment date & Servicing $\mathrm{db}$ \\
\hline Margin & $\begin{array}{l}\text { Basis points added to the ARM index to determine the coupon } \\
\text { rate of the ARM loan }\end{array}$ & Servicing db \\
\hline CLTV & $\begin{array}{l}\text { Ratio of the first- and second-lien amount to the sale price? of } \\
\text { the house at the time of purchase }\end{array}$ & Public records \\
\hline FICO & FICO (credit) score of borrower at time of loan origination & Servicing db \\
\hline Low or no documentation & Indicator equal to one if loan documentation was not complete & Servicing db \\
\hline Back-end DTI & $\begin{array}{l}\text { The total monthly liabilities of the borrower, including the debt } \\
\text { on the subject property, divided by the total monthly income of } \\
\text { the borrower(s) }\end{array}$ & Servicing db \\
\hline $\begin{array}{l}\text { Adjustable rate mortgage } \\
\text { (ARM) }\end{array}$ & $\begin{array}{l}\text { Indicator equal to one if mortgage rate is determined by a } \\
\text { spread over a floating index }\end{array}$ & Servicing $\mathrm{db}$ \\
\hline $\begin{array}{l}\text { Fixed rate mortgage } \\
\text { (FRM) }\end{array}$ & $\begin{array}{l}\text { Indicator equal to one if mortgage rate is determined by a fixed } \\
\text { coupon rate }\end{array}$ & Servicing $\mathrm{db}$ \\
\hline Negative amortization & $\begin{array}{l}\text { Indicator equal to one if mortgage has a provision that allows } \\
\text { monthly payments below the interest coverage amount, rolling } \\
\text { the difference into the principal balance }\end{array}$ & Servicing $\mathrm{db}$ \\
\hline Interest only & $\begin{array}{l}\text { Indicator equal to one if mortgage has provision that allows } \\
\text { monthly payments to cover only interest owed, rather than } \\
\text { interest plus amortization of the loan balance }\end{array}$ & Servicing $\mathrm{db}$ \\
\hline Prepayment penalty & $\begin{array}{l}\text { Indicator equal to one if mortgage has provision that assesses a } \\
\text { penalty to the borrower if a loan is prepaid }\end{array}$ & Servicing db \\
\hline Log tract 2000 med inc & Median income of households within a census tract in 2000 & Census \\
\hline Freddie 30 -yr rate & $\begin{array}{l}\text { Interest rate for } 30 \text {-year fixed mortgages published by Freddie } \\
\text { Mac }\end{array}$ & Freddie Mac \\
\hline Fed Funds rate & $\begin{array}{l}\text { The interest rate at which depository institutions trade balances } \\
\text { held at the Federal Reserve }\end{array}$ & Federal Reserve \\
\hline Regional home prices & $\begin{array}{l}\text { A home price index at the county level constructed from the } \\
\text { mortgages in this dataset }\end{array}$ & Public records \\
\hline $\begin{array}{l}\text { State-level } \\
\text { unemployment }\end{array}$ & Quarterly state unemployment rates & Bureau Labor Statistics \\
\hline Log annual number loans & $\begin{array}{l}\text { Log of the number of loans originated by each lender within this } \\
\text { dataset }\end{array}$ & Public records \\
\hline Lender independent & Indicator equal to one if lender does not have a parent company & Researcher \\
\hline Parent public & Indicator equal to one if parent company is publicly traded & Compustat \\
\hline Parent log assets & Log of the parent assets if parent company is publicly traded & Compustat \\
\hline Lender JV with bank & $\begin{array}{l}\text { Indicator equal to one if homebuilder's lending unit is a joint } \\
\text { venture with a financial firm }\end{array}$ & Various \\
\hline
\end{tabular}

